\title{
THE MULTIPLY PRODUCED FILM: Collaboration, Ethnography, and Feminist Epistemology
}

\author{
EMILY HONG \\ Haverford College \\ (D) https:/ / orcid.org/0000-0002-9901-436X
}

It was a sweltering day in August, but I needed the exercise. After turning the corner to my block, my jog slowed to a walk. When we recognized each other, Milton's face widened into a smile, revealing a few lost teeth. I offered a sweaty hug, and asked what he was doing in the neighborhood, Ithaca's Southside, in central New York. "Waiting for Stanley. He lives here!" I looked over to the house; it seemed more run down than before, but I recognized the place; we had filmed a scene here a few years back when I followed Milton Webb and Stanley McPherson, two recycling workers and labor activists, for a film about their fight for a living wage called Get By (Hong 2014). The local campaign in which Stanley, Milton, and I were active was and is part of a larger movement across the United States to promote turning a minimum wage into a "living wage"-one regularly recalculated to account for basic living expenses such as rent, food, and health care. ${ }^{1}$

I told Milton I had just moved into the neighborhood, with friends who- $\mathrm{I}$ now realized — lived across the street from Stanley. Stanley's apartment, a room in an aging house, wasn't out of place; several houses on our street were dilapidated or abandoned. Our next-door neighbor had been evicted when she fell behind on bills for the day care she ran out of her home. 
“How is Madison?" I asked. In one scene of our collaborative film, Milton talks about his then-newborn daughter and his hope that she would benefit from his struggle for a living wage for all workers. It felt hard to believe she was now five years old. "I heard about Paula, I'm so sorry." Madison's mom had passed away when I was overseas. Milton explained that the day before she died, he had taken her to the hospital. Milton knew Paula was off drugs and insisted she be examined; but doctors refused to see her, adamant she go to rehab instead. A year later he was still grieving and in disbelief at the broken system - revealed through this tragedy to be racist, classist, and ultimately responsible for Paula's death.

"You know what? You can do us a huge favor." With a glimmer of hope in his voice, Milton reached out and touched my arm. "Can you work the studio cameras for our show? Our volunteers are gone now.” After work, Stanley and Milton hosted a public-access TV show, What Matters at the Round Table (McPherson and Webb 2014), where they offered a critical working-class lens on the latest headlines. Milton's request was no small ask, but rather a weekly commitment with no end in sight. Live television production would also differ from what I was familiar with, ethnographic filmmaking. Still, I found myself agreeing immediately. Throughout the making of Get By, my relationship with Stanley and Milton had been shaped, and in many ways, produced, by a series of exchanges - mediated (e.g., their support for "my" film and my support for "their" TV show) and unmediated (e.g., acts of friendship and solidarity). I eagerly offered this delayed return-gift, which, like those before, took the tone of part obligation and part shared mission. ${ }^{2}$

From the beginning, I had conceived Get By as an exploration of collaboration across difference - worker-community solidarity across lines of race and class. I also hoped to explore how the filmmaking process itself might constitute collaboration. Paradoxically, I found difference where I expected commensurability, and vice versa. Looking to document solidarity, I found an underlying discourse of class and race-based distancing. I was surprised, for instance, to hear white owning-class activists identify more with the county government than with the workers they ostensibly fought for. As one activist put it: "They do an important public service, even as private contractors, and we ought to pay them a living wage." At an event I helped organize, Stanley, who like Milton is Black and working class, pointed to a close ally, the white, middle-class director of the local workers' center, and said, "people like him don't want people like us living in their neighborhood, and they will do whatever it takes to keep us out." Stanley's phrasing underlines a core 
insight of feminist anthropology, that class does not exist outside of its relation to race and other forms of difference (Bear, Ho, Tsing, and Yanagisako 2015).

By contrast, I found overlapping interests where I expected incommensurable difference; Stanley and Milton are two decades older than me, a multiracial middle-class woman of Asian, European, and Middle Eastern heritage. As a PhD student at an Ivy League institution at the time, I was afforded significant class privilege, despite my own income hovering under the living wage. Throughout the article, I discuss various moments in which asymmetries in class, race, and gender were made to matter. Despite these differences, shared experiences with activism, media-making, and housing insecurity brought us closer together, at times eclipsing, however contingently, barriers of age, race, class, and gender. In this way, a film seeking to document the dynamics of worker-community solidarity ultimately shed light on a different kind of asymmetrical collaboration - the filmic collaboration behind its creation.

In this article, I draw on ethnographic and autoethnographic material from the production and distribution of Get By, recasting concepts in the anthropology of exchange through a feminist and decolonial lens. I take up Zoe Todd's (2018) provocation of a Decolonial Turn 2.0, or a Decolonial (re)turn, that to challenge the colonial structures of our trade, we must re-engage that which anthropology has previously explored with an ethos of "growth, change, and doubt." I revisit concepts from the anthropological study of "asymmetrical exchange" and apply them to an analysis of anthropology's core method - ethnography — what I argue is an inherently asymmetrical exchange of labor situated at the intersection of gift and commodity economies.

Drawing on Marilyn Strathern's (1988) The Gender of the Gift and other classics in economic anthropology, I conceptualize the "multiply produced film" as a methodology and analytic that situates asymmetrical dynamics inherent to ethnographic filmmaking within everyday relations of exchange. The multiply produced film as a method invites the sharing of authorship and creative authority through fluid and changing roles in ways that do not refuse difference but recognize its transformative potential. As an analytic, it unearths the process of collaborative filmmaking beyond the moments of filming, revealing how a film created through collaborative means can take on the characteristics of commodity as much as gift. Though I focus on ethnographic film, the "multiply produced" offers an approach to thinking about the broader asymmetrical dynamics of the ethnographic method in and beyond the field, once knowledge relations become sutured into material objects. 
To begin, I situate the multiply produced film within a feminist and decolonial genealogy of anthropology, drawing a thread between ontological insights from the anthropology of exchange and the epistemological contributions of feminist, decolonial, and visual anthropologists committed to collaborative methods across various axes of difference. In the remainder of the article, I work through ethnographic and autoethnographic dimensions of Get By's production and distribution. The first ethnographic section revisits the film's production stage to explore methodological and epistemological dimensions of the multiply produced film. I describe the ways in which the filmmaking process bumped up against Western conceptions of autonomy and authorship. I then show how the multiply produced film entails working across asymmetries through shifting roles, setting forth a cascading multivocality that transformed the resulting filmic form.

The latter ethnographic sections explore the ontology of the multiply produced film — as gift and commodity — through its post-production and distribution stages using two concepts from the anthropology of exchange-alienability and mutability. Alienability is a category used to distinguish between an object as commodity or gift — the question being whether said object can be separated from the relations that produced it. Mutability is an object's capacity to be refashioned from a commodity to a gift, or vice versa, or to be commodity and gift at once. Together, these concepts help explain some of the paradoxical dynamics emerging from the production and circulation of ethnography's artifacts (e.g., films, books). Finally, I show what happens when, facilitated by spatial and temporal separations, Get By exhibited aspects of mutability between gift and commodity, pulling asymmetries of collaboration into focus.

Like feminist anthropologists before me, I embrace reflexivity and autoethnography as essential tools in attending to the inherent ambivalences of collaborative ethnography, namely, the asymmetrical dynamics at play (Trinh 1992; Sudbury and Okazawa-Rey 2009) and the impossible desire to mitigate them through collaborative practices. In offering autoethnographic description, I do not have prescriptive aims regarding an idealized vision for collaboration; rather, I seek to account for the complexities of being an ethnographer who, acting in solidarity, necessarily forms one part of a complex equation of power and perspective (Ulysse 2007; Perry 2014). Furthermore, as feminist scholars have shown, autoethnography has a peculiar power to illuminate structures of inequality by elucidating individual experiences and socioeconomic realities with a single stroke of the pen (Griffin 2012; Anzaldúa and Keating 2015). 


\section{ETHNOGRAPHY AND SOLIDARITY AS ASYMMETRICAL}

\section{EXCHANGE: Contributions of Feminist, Decolonial, and Visual}

\section{Anthropology}

In recent years, collaboration has witnessed a surge of interest in anthropology and broader public life. Within anthropology, the methodology of collaborative ethnography has been fruitfully explored in the fields of engaged anthropology, public anthropology, activist anthropology, participatory action research, and the anthropology of collaboration (e.g., Hemment 2007; Lassiter 2008; Rappaport 2008; Low and Merry 2010). The latter concerns itself with collaboration as both the object and method of fieldwork and is increasingly gathering insights from anthropology's long-term interest in exchange relations, or "the gift" (Jackson 2004; Faubion and Marcus 2009; Rabinow 2011; Riles 2015). The anthropology of collaboration-like its forebears in the anthropology of exchange-has often emphasized the sociality of collaboration, sometimes at the expense of eliding asymmetries of power. Landmark studies on "asymmetrical exchange" along lines of gender (e.g., Strathern 1988; Weiner 1992; Guyer 2004) and colonialism (e.g., Asad 1998 [1973]; Fabian 1983; Comaroff and Comaroff 1991; N. Thomas 1991), while once revelatory, have not fundamentally transformed anthropology's most treasured method — ethnography — arguably an inherently asymmetrical exchange.

The "decolonizing generation" (Allen and Jobson 2016) of the 1980s and 1990s recognized a key lesson from the anthropology of colonialism: that the conceit of social scientific neutrality (i.e., "value free" anthropology in the vein of Bronislaw Malinowski [1929] and E. E. Evans-Pritchard [1946]) played into colonialism as much as any explicit alignment with colonial powers (Pels 2008, 291). While the lack of agreement around how to do anthropology differently has stymied the discipline's ability to fully come to terms with its colonial past, scholars of feminist, decolonial, and visual anthropology have made important methodological and epistemological interventions. Among these ranks the recognition that the dispersal of intellectual authority required by decolonial anthropology cannot be limited to expanded archives or purely textual experiments, but instead necessitates concrete collaborations between ethnographers and so-called informants (Fabian 1983; Harrison 1991, 5). Recognizing the impossibility of neutrality, feminist and decolonial anthropologists have also continued to grapple with political positioning and its relation to epistemology as necessary tools for decolonizing anthropology (Harrison 1991; Visweswaran 1994; D. Thomas 2018). ${ }^{3}$

Taking up this baton, scholars in feminist and decolonial studies have made significant epistemological strides, demonstrating how knowledge is transformed 
when moving beyond anthropology's classic subject-object dyad. Trinh T. Minh-ha's $(1992,87)$ work insists on a reflexive ethnographic and filmic voice that "does not objectify"; her approach to "speaking nearby" "reflects on itself and can come very close to a subject without, however, seizing or claiming it." Kim TallBear's (2014, 2) feminist-Indigenous concept of "standing with" entails a preparedness not only to "stand with" a "community of subjects" but a "willing[ness] to be altered, to revise her stakes in the knowledge to be produced." Like Trinh, TallBear moves beyond the subject-object dyad to illuminate the relationship between positionality and epistemology-how knowledge and the self can be transformed through the collaborative process.

Amid calls for a Decolonial Turn 2.0 (Todd 2018) and "the case for letting anthropology burn" (Jobson 2020), visual anthropology has taken on new significance as an arena for understanding and potentially transforming the hierarchical dynamics of ethnography. While not all visual anthropologists pursue collaboration with their film "subjects," an increasing number are committed to explicitly political, public, and decolonial approaches (Ginsburg 2018; Dattatreyan and MarreroGuillamón 2019). Through collaborative and reflexive work, scholar-artists have underlined the epistemological difference that power makes in the dance between ethnographic filmmaker and subject. ${ }^{5}$ They also increasingly concern themselves with the ways that, despite popular framings of avant-garde art films as "noncommercial" and multimodal technologies as "democratizing," such modalities remain enmeshed in hierarchical economies of prestige and capitalism (Lee 2019; Takaragawa et al. 2019).

Through what I call the multiply produced film, I contribute to these feminist and decolonial approaches a concrete (auto)ethnographic examination of collaboration, focusing on solidarity, relational autonomy, and the transformation of value across asymmetries of power. While much has been written about the attempts of co-authorship to place interlocutors on an equal playing field, this is often an impossibility because of the need for consistently shared priorities, time, or privilege (Payne and Bryant 2018; Torres 2019). By focusing on relational autonomy and the transformation of value, the multiply produced offers a lens for those gray areas of collaboration that reflect ethnography's limitations, its inherent asymmetries, as well as unique potentialities - its valuation of open-endedness, multivocality, experimentation, and multiple positionalities. ${ }^{6}$ In my examination of solidarity as subject matter and method, I follow feminist and queer theorists of color in seeing solidarity as a form of alliance-building that acknowledges always implicated relations of power (Mohanty 2003; Atshan and Moore 2014; Liu and Shange 2018). 
While feminist accounts of collaboration emphasize the intersectional dynamics of directly involved parties - the researcher and the researched-solidarity brings into view the presence of not two but three parties. As Jodi Dean $(1996,3)$ puts it, "I ask you to stand by me over and against a third." If anthropology's complicity in colonialism resulted from willful ignorance of a more powerful "third" party, an examination of solidarity has great implications for pathways beyond the subject-object dyad of classic ethnography.

In this collaboration, my solidarity with Stanley and Milton was formed "over and against" (Dean 1996) two entities complicit in the refusal to pay a living wage - the recycling corporation and the county government that contracted them. From the start, this shared political analysis oriented our work on the campaign and the film, shaping a common goal that transcended the classical dyad of researcher and researched. What became clear much later is that the film's "use value" for the campaign stood in tension with the "exchange value" it took on beyond our activist goals, challenging the gift-like nature of our collaboration. Once the film hit the film festival circuit, other parties came into the picture; the material object of the film that appeared more gift-like in the context of friendship and collaboration took on commodity-like elements.

In what follows, I discuss the repeated acts of reciprocity, friendship, and allyship that constitute the contingent "we" of solidarity in the production phase; I then describe the tensions that arise when such dynamics of solidarity are put to the test in the distribution phase. The lens of the multiply produced film offers a way to explore the dynamics of asymmetrical exchange in the seemingly symmetrical collaborative sphere of production and the more sobering sphere of distribution, where conventions of single authorship abound.

\section{THE MULTIPLY PRODUCED FILM: Autonomy, Solidarity, and the Gender of the Gift}

Evidenced by the long credits of many films, filmmakers consider their craft collaborative by necessity. Yet, like other fields in the arts, filmmaking rewards the notion of a visionary genius director. The common occurrence of a film premiere as the place where film protagonists see their lives on screen for the first time reflects this ideal. Inevitably shaped by this ethos through my own training in filmmaking and fine arts, I began the project with an unresolved ambivalence about collaboration. I wanted to collaborate, but hesitated about how and to what extent I could while retaining my own vision. I explained the idea behind the film to Stanley and Milton, asking for input and ideas but making no formal ar- 
rangements for collaboration. Seasoned filmmakers advised me to retain as much "artistic autonomy" as possible. Underlying their advice was a belief that a degree of consultation would secure cooperation, but too much would constrain the film's artistic potential, relegating it to a conventional "talking heads" advocacy piece.

This emphasis on supposed autonomy chafed against my own inclinations as an active organizer in the living wage campaign. Yet I, too, felt wary of attempting to flatten all differences between filmmaker and subject, ethnographer and collaborator. I was familiar with the work of so-called insider activist-anthropologists who see themselves primarily as translators or spokespersons, but I felt such work left out insights made possible by those embracing an insider-outsider positionality (Abu-Lughod 1988; Narayan 1993; McClaurin 2001; Simmons 2001; Slocum 2001; Jackson 2004; Fassin 2012). ${ }^{7}$ By refusing to give up either position as "native" insider or outside social scientist, such scholars recognize the "contradictory, multilayered, engaged" and richer knowledge resulting from this dual positionality (McClaurin 2001).

I had found comfort in the possibility of standing at what Didier Fassin (2012, 245) describes as the epistemological "frontiers of Plato's cave," neither fully inside nor outside. What I found promising about this approach was the prospect that ethnographic critique could be informed by the ambivalences and reflexivity of interlocutors without abandoning the ethnographer's autonomy, however partial. What I learned from making Get By was the need to move beyond this productive but ultimately dualistic metaphor for knowledge production, one that captured the ethnographic insight that a better film involved defying singular ideals of autonomy and authorship. Such a metaphor would need to transcend the subject-object dyad of classic ethnography to recognize that my collaborators could occupy multiple positions as reflexive film protagonists and co-producers while capturing the epistemological difference that difference makes.

The multiply produced film draws inspiration from the multiply produced Hagen pig, an object of interest in Strathern's (1988) The Gender of the Gift. To understand domination in non-commoditized economies, Strathern $(1988,161)$ argues that we must discard two Western assumptions about authorship: ownership and the individual agent who authors their own acts. In Hagen pig production, she writes, "neither the woman's nor the man's work can encompass that of the other partner. The pig is multiply produced . . . . As a product of the relationship between the conjugal partners, the pig is not reducible to the sole interest of either party" (Strathern 1988, 160). While Strathern's work highlights gender as the 
primary axis of difference within the dynamics of asymmetrical exchange, Get By's production emphasized asymmetries of gender, race, and class.

Two months into filming, unforeseen circumstances shifted my initially cautious approach, propelling the film toward a multiply produced, unpredictable endeavor. By then, I had hours of cinéma vérité footage — of protests, activist meetings, legislative events, and Stanley raking leaves at church and playing drums for the choir. ${ }^{8}$ One autumn day, in a major shock to him and others in the living wage campaign, Stanley found himself fired from his job. He had attempted to warn a white woman dropping off her garbage about safety precautions. Apparently finding his demeanor threatening, she reported this "angry Black man" to his supervisor, giving the company the perfect excuse to terminate one of two longtime workers whose activism they perceived as troublemaking. As Stanley reveals at the end of the film, "A thousand signatures went to them and my name was on the top of that list. . . That right there gave them grounds that 'hey, I'm gonna get rid of this guy because he's asking for money_a living wage."

Stanley's firing was a catalytic reckoning for two forms of collaboration across difference - the worker-community solidarity I sought to document and our work together behind the camera. I will take up each of these in turn. When I filmed the first scene - the protest in front of the recycling facility - the worker-community solidarity at the heart of the campaign began to reveal itself for what it was. The abstractness of solidarity for some white middle- and upper-class coalition members who signed petitions and showed up to protests became apparent. In the opening scene, Martha, a sweet and slow-moving older white woman, expresses surprise when she discovers that Stanley, the Black man protesting alongside her, is the worker-leader whose name she has seen in campaign press releases; they shake hands. As student organizers finish rolling up protest banners, Milton puts his arm around Pete, the director of the workers' center and says, "Pete keeps us going, we keep Pete going, but we need a living wage." This moment gestures to the political affects undergirding the seemingly reciprocal foundations of solidarity, one that would ultimately unravel.

This solidarity proved fragile for two reasons, first in a way best explained in contrast to Roseann Liu and Savannah Shange's (2018) concept of "thick solidarity." Focused on contemporary Asian-Black coalitions rooted in differing histories of oppression (e.g., chattel slavery and indentured servitude), the authors define thick solidarity as one "that mobilizes empathy in ways that do not gloss over difference, but rather pushes into the specificity, irreducibility, and incommensurability of racialized experiences" (Liu and Shange 2018, 190). The fragility of the 
living wage coalition's solidarity stemmed partly from its mobilization of empathy that papered over differences of the classed racialities and racialized class subjectivities of coalition members (see Hall et al. 1978; Jackson 2010).

Solidarity also proved "thin" in another way. Abstract solidarity is misleadingly effective in its mobilization of affect; the campaign used Milton and Stanley's voices and images as "poster children" with great success, creating an impression of full agency in terms of their leadership. Only when the fissures of coalition unity expanded in moments of crisis did a picture of who truly held power in apparently equal relations of "solidarity" become clear.

While conceptually powerful, Liu and Shange's (2018) treatment does not fully explore the how of thick solidarity. The incommensurability of intersectional differences of class, race, and gender can be difficult to comprehend in the abstract; perhaps they can only be understood through the embodied experiential knowledge of friendship and accountability. In other words, it is through everyday relations of exchange forged through the affective work of organizing together for a shared cause, often "over and against" a powerful other, that we are forced to grapple with "our interconnectedness and our interstices" (Liu and Shange 2018, 195). What precisely constitutes that solidarity — its sturdiness or hollownesscan only be known at points of crisis, personal and political. When push comes to shove, will the person whose back you have had for months have yours?

Years later, working on Stanley and Milton's TV show, I would learn that, when I was in crisis, about to be kicked out of housing by a landlord I thought was a friend, they had my back. But during the campaign, when Stanley found himself in crisis, fired from his beloved job, the community that showed up at meetings and even protested alongside him did not have his. Despite initial outrage over his firing, behind closed doors, the white middle-class leaders of the campaign raised doubts as to whether Stanley's firing was as groundless as he claimed. From my perspective, these justifications for inaction were muddied by raced, classed, and gendered assumptions that shared more empathy with Stanley's employer and the white woman customer that had reported him than with Stanley himself. The campaign ultimately continued, with Stanley's undying commitment to the cause, but not without the stain (which I sometimes felt was only visible to me) of an utter failure of accountability to the person who had risked the most for its success. To this day, I harbor regret for not being able to convince the white leaders of the campaign to do more; when I said earlier that my decision to join the crew of Stanley's TV show was motivated by part shared mission and part obligation, in 
retrospect it may have been a delayed return-gift not only for the film but for the collective debt of solidarity in which I was implicated.

After his termination, I saw a shift in Stanley, who had always been outgoing and outspoken. With this inward turn, he became less enthusiastic about everything, including shoots for the film. Until then, Milton had been the "quiet" one; unlike Stanley, he hadn't offered ideas for shoots. My subsequent request for Milton's direct input, against prevailing norms of artistic autonomy, would become the most significant choice I made on the film. ${ }^{9}$ Milton turned out to have tremendous insights into how to translate experiences of working-class poverty and racism into the aesthetics of the film.

Stanley was always eager to be in front of the camera, but Milton had a clear sensibility for what happens behind it. After a few prompting questions, he already began thinking like a director-producer. "We need to show people what poverty looks like," he said with certitude. He wanted people to "see" the difference between a minimum wage ( $\$ 7.25$ in New York State at the time) and a living wage (\$12.62 in the county at the time). A week later, on a bitterly cold evening, we shot the scene Milton had envisioned-him walking down the street toward my camera as it was wheeled back on a low-budget dolly (i.e., wheelchair). In the scene, he reminisces about the neighborhood he grew up in, pointing to the differences between a minimum-wage neighborhood and a living-wage neighborhood, and the life opportunities each affords.



Film Clip 1. Milton reminisces about the "minimum-wage" neighborhood he grew up in. Film clip from Get By (2014). https:/ / media.dlib.indiana.edu/media_objects/5h73qg52m. 
Notably, we did not shoot this scene where Milton lived - a more rural neighboring village - but in an urban neighborhood he felt best represented a "minimum-wage" neighborhood. The resulting scene can be understood as "ethno-fiction" (Rouch 2003 [1973]), a filmmaking form blending fiction and documentary through creative improvisation where ethnographic collaborators play versions of themselves.

Another important moment of collaboration prompted a cascading multivocality - an unforeseen chain of events in which one move toward multivocality, beginning with Milton's vision, led to yet more voices, and ultimately a more complex and open-ended filmic narrative. The spark for this process occurred when I showed Milton a rough cut of the film in progress, a moment also captured in the film. Sitting in front of the editing station, Milton reflects on the scenes, proceeding to tell me that the film needs perspectives beyond his and Stanley's. The film then cuts to the scene filmed as a result of this conversation, in which he conducts so-called man-on-the-street interviews. He approaches passersby, including a UPS driver and owners of a local barbershop, and asks them point blank, "What do you think of the living wage?"

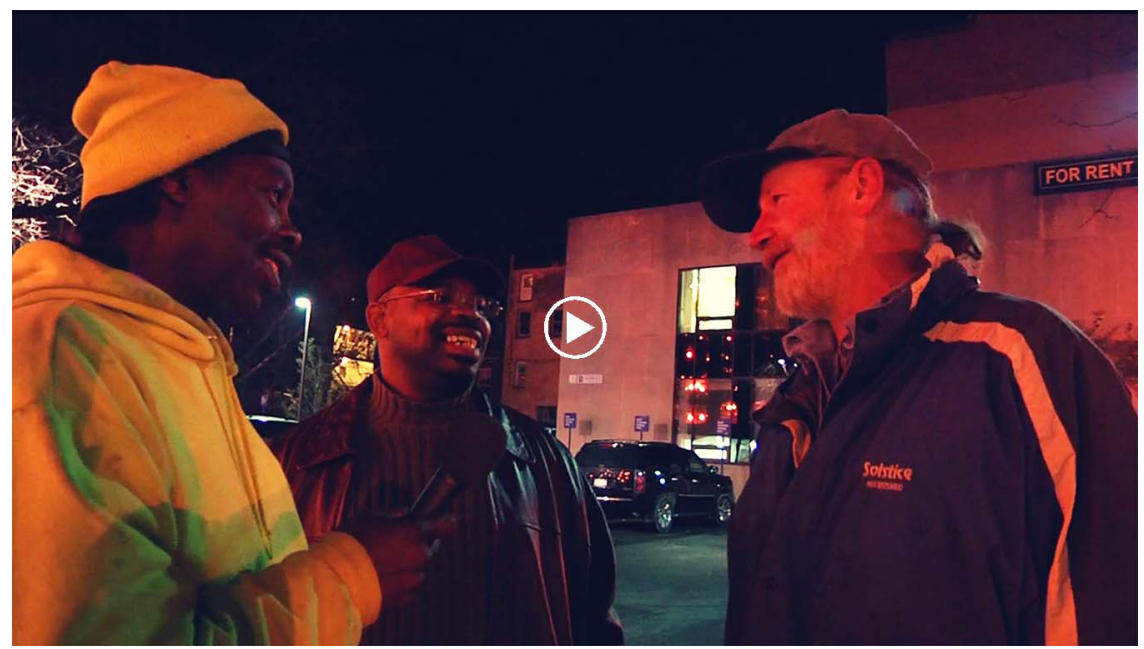

Film Clip 2. Milton and Stanley conduct man-on-the-street interviews to gauge local perspectives on the living wage. Film clip from Get By (2014). https://media.dlib.indiana.edu/media_objects/hx11z2189.

While initially unsure of how such interviews would fit into a largely observational film, I enthusiastically included them in the final edit, since they contributed to a more nuanced, multivocal narrative. In contrast to typical man-on-the- 
street interviews, the scene suggests a tight-knit community; it is apparent that interviewees know Milton well or have seen him speak. Despite such familiarity, each offers a contrasting perspective on the living wage, complicating any singular emergent activist narrative. ${ }^{10}$ The scene also reveals the racialized dynamics of a predominantly white city. A white man who saw Stanley and Milton speak at a rally does not even recognize them; one of the Black barbershop owners feels the need to speak against racist stereotypes about Black wealth, pointing to his watch and saying to the camera, "this doesn't come from drug money."

One way to gloss the story of Get By would be to say that the process that made it more collaborative also led to a better film. Of course, the story is more complicated. Much of the film's production process involved thinking with and eventually against the overarching filmmaking norms I was trained in-ones suggesting I should retain my artistic autonomy, and if necessary, create two versions of the film, an "activist" version for them and another for myself. I could not articulate it then, but this perspective intuitively went against my raced, gendered, and classed positionality as an insider (activist)-outsider (ethnographic filmmaker) and the values I hold, shaped by my experiences as a first-generation Asian American immigrant and activist. I was aware of the complex U.S. histories structuring Black-Asian solidarities and racialized conflict. ${ }^{11}$ My activist education in social movement spaces taught me that my relative class and racial privilege often meant that true solidarity entailed stepping back to center the agency of those more directly affected.

Western ideals of autonomy project an inherent tension between acting in one's own interests and meeting the obligations inherent to the sociality of the gift economy. By contrast, Strathern $(1988,90)$ describes the emergence of Hagen autonomy as the moment a child realizes the importance of interdependence and reciprocity in social relationships. This focus on the interdependence of autonomy is one I strongly identify with through my own acculturation. ${ }^{12}$ As the director, cinematographer, and editor of a film focused on the experiences of two working-class Black activists, my exercise of relational autonomy entailed a conscious decision to share my authority — a risky move as a woman filmmaker. As a director, I have mostly worked with woman-identified crews and protagonists, and have still found my authority questioned by male passersby while filming in public. ${ }^{13}$ While sharing authority as a female director is never simple, feminist ethnographic collaboration always entails dangers (Stacey 1988; Visweswaran 1994). With Get By, however, my move to share authority led to a cascading multivocality in the filmmaking process and its resulting form. 
The multivocality of this multiply produced film thus had implications for epistemology - in this case filmic narrative and form - in ways I could not have anticipated. It allowed Milton to shape the narrative of the film not only as a campaign poster child - a position to which he and Stanley were often circumscribed - but as a media-maker in his own right. At times, Milton put on the director's hat, challenging me to make space for more voices, including other working-class members of the community. In this way, it was not only I who had the autonomy to "stand at the frontiers" (Fassin 2012); Milton too, occupied that double position as "insider-outsider," contributing personal perspectives and creative and critical analysis. Thus I experienced our artistic and authorial autonomy as inextricably intertwined.

As a collaborative method that favors sharing authority and creating openings for multivocality, the multiply produced film shares resonances with Participatory Action Research (PAR), but important differences remain as well. Participatory Action Research is described as the collaborative design and execution of change-oriented research through partnership between researchers and "stakeholders" (Greenwood and Levin 2007, 3). Critiques leveled at PAR resemble those aimed at impact filmmaking, an approach in nonfiction film that is sometimes celebrated but often considered suspect for its social change-oriented agenda. One concern articulated about both PAR and impact-oriented collaborative filmmaking is how the lead researcher or director's perceived lack of autonomy may translate into "positivist" and "uncritical" research (Hale 2006; Juris and Khasnabish 2013) or "propagandist" films lacking "production value." With Get By, I found that stakeholder involvement made the film more multivocal and open to interpretation, rather than prescriptive. The multiply produced film shares core values with PAR and activist ethnography — and at the intersection of the two, "Street PAR" (Bryant and Payne 2013; Payne and Bryant 2018) — particularly their focus on accountability and shared knowledge creation. It departs, however, in its valuation of two aspects of feminist ethnography, namely, open-endedness and multivocality. ${ }^{14}$

While recognizing the countervailing forces incentivizing single authorship, the multiply produced film builds on the feminist tradition to emphasize a cascading multivocality attuned to various axes of difference that are evident at the start, may emerge over time, and are continually transforming. ${ }^{15}$ This unpredictability prompts constant reflexivity and recursivity to questions of creative authorship. Here it is important to highlight intersectionality - the multiple intersecting dynamics of difference and sameness (Crenshaw 1991; Simmons 2001; Cho, Crenshaw, and McCall 2013). For some projects, like Kai M. Green's (2011) It Gets 
Messy in Here, shared identities (in this case, trans and racial identities) enable a unique "co-collaboration" between filmmaker and subject, while recognizing the filmmaker's inherent power (Green 2015). For others, like Get By, some shared identities as media-makers and activists can create opportunities to address differences of race, class, and gender, and seek — however fraught and unstable - epistemologies of solidarity.

\section{FILM AS GIFT AND COMMODITY: Dynamics of Alienability and Mutability}

Initially, the filmmaking process was animated by simple reciprocal forms of exchange in the shadow of a greater purpose - the living wage campaign. First, I asked Stanley and Milton to share their experiences through on-camera interviews. Soon, they asked me for help recruiting guests for their TV show. Such exchanges became more complex and overlapping over time, bringing together our media, activist, and personal worlds. As acts of friendship, allyship, and solidarity, these exchanges intensified after Stanley's termination. I contacted a labor expert at my university to ask for legal advice about his dismissal. Stanley and Milton visited Cornell to speak at an event I organized to mobilize more solidarity for the campaign. In this event - and film scene — Stanley makes two announcements tinged with disappointment and pride. Stanley, wearing a suit, is sitting next to Milton, who having just finished a shift, sports a neon yellow recycling worker's vest. Stanley shares his dismissal in a subdued manner; he quickly moves on to the good news, holding up his photo in the newspaper. The news article details not his dismissal but a significant win for the campaign. Thanks to the coalition's efforts, the county legislature finally made a motion to put $\$ 100,000$ toward a "living wage contingency fund"- to provide subcontracted workers like Stanley and Milton a living wage when direct employers were unwilling to do so.

Our increasingly overlapping exchanges continued after completing film production. When the mayor of Ithaca cancelled his appearance on their TV show at the last minute, Stanley called me, pleading that I appear instead. He asked that I bring clips of the film to broadcast live on the show, something I hesitated to do, since Stanley had not yet seen the final film. My anxiety was allayed halfway through the live broadcast when, nodding vigorously, he expressed approval of the clips. It marked the first time since his dismissal that I had seen Stanley back to his enthusiastic self.

Cuts from Stanley and Milton's show already constituted a scene in my film (see Film Clip 4), and excerpts from my film were featured on their show. By the 


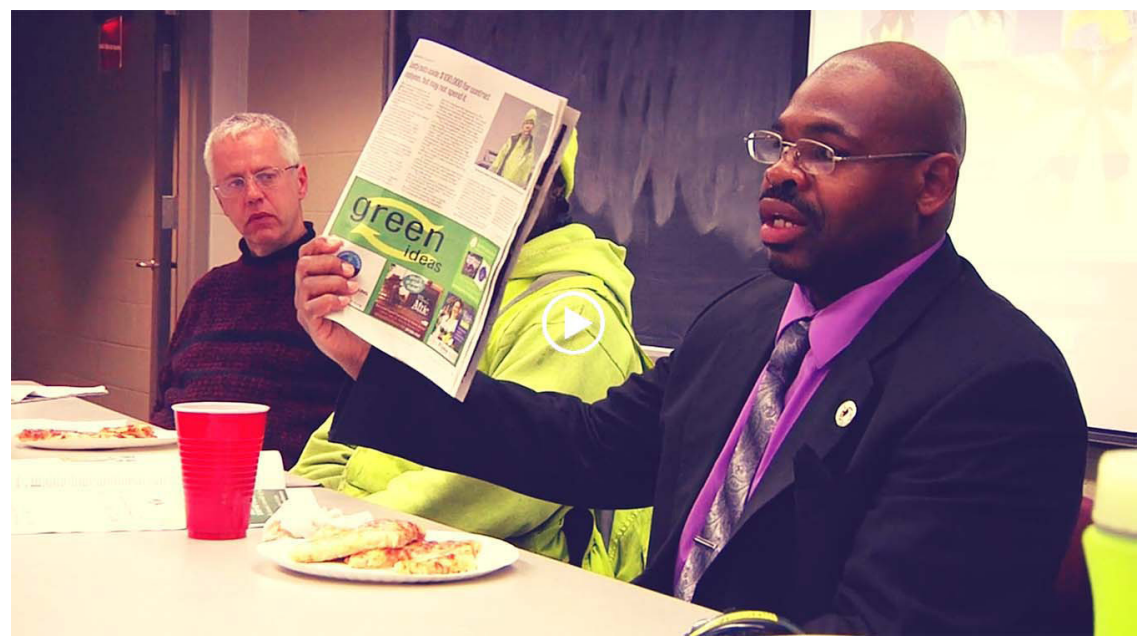

Film Clip 3. Stanley makes two important announcements. Film clip from Get By (2014). https://media.dlib.indiana.edu/media_objects/dv140d42s.

time I agreed to appear as a guest on the show, however, it seemed that the occasion intended to promote our film and our campaign. The film had become an object I could no longer claim for myself; to recast a key term from the anthropology of exchange, the film had become far less alienable than I had imagined it could be. The material intertextuality of our media projects - that the film was part of their show and vice versa-became apparent not only because Stanley and Milton produced their own TV show but also because both the show and the film were unpaid endeavors motivated by overlapping political goals. Our shared experience as media-makers and organizers in the living wage campaign contributed to an ethos of care and collaboration that manifested in terms of relations and intertwined artifacts. While these unique circumstances and, more broadly, the convergence of the film's content and methodology (regarding the politics of solidarity and the value of labor) played a considerable role in surfacing the inalienability of the film, as I will show, such dynamics persist in the drawn-out production and circulation of many ethnographic artifacts, such as books and films.

\section{ALIENABILITY THROUGH A SET OF SYSTEMATIC SEPARATIONS}

Within the anthropology of exchange, alienability represents a characteristic used to distinguish between commodity exchange, the exchange of alienable things between independent parties, and gift exchange, the exchange of inalienable things between dependent parties (Gregory 1982, 12). I have previously described the collaborative process through which a Hagen pig is multiply produced; because 


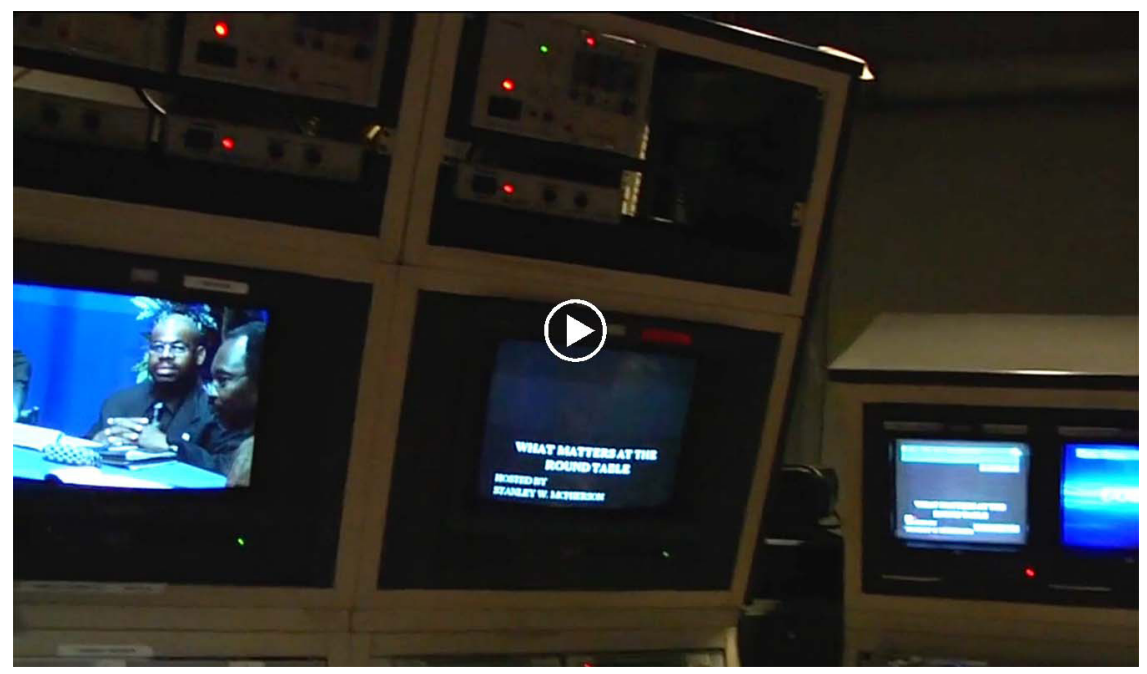

Film Clip 4. What Matters at the Roundtable, a TV show hosted by Stanley McPherson and Milton Webb. Film clip from Get By (2014).

https://media.dlib.indiana.edu/media_objects/m900pd17b.

it is irreducible to the sole interest of either spouse involved in its production, the pig can be understood as inalienable (Strathern 1988, 160). In this section, I examine whether owing to the multiply produced dynamics of its production, Get By can also be understood as inalienable.

Feminist anthropologists have challenged the fetishized value placed on single-authored scholarship, often considered the gold standard of achievement, given that its creation and circulation hinges on exclusion (e.g., publication paywalls) and power imbalances (e.g., the appropriation of knowledge from outside the academy for advances within its prestige economy) (Torres 2019; El Kotni, Dixon, and Miranda 2020). Re-reading Strathern's ethnography of pig production within a gift economy sheds incisive light on this claim, underlining the importance of examining collaboration beyond the sphere of production. The following passage explicates how, despite the shared role of spouses in pig production, the potential for men's domination stems from their disproportionate role in the sphere of circulation, facilitated by a set of "systematic separations." For a thought experiment, I insert the words filmmaker/anthropologist and film/ethnography after "man" and "pig," respectively.

Hagen men [filmmakers/anthropologists] claim singular responsibility of a kind: as wealth pigs [films/ethnographies] are freshly conceptualized as the result of men [filmmaker/anthropologist]'s transactions, and thus their value 
in exchange is the value that men [filmmakers/anthropologists] have given to them. . . . There is a one-to-one relationship between a man [filmmaker/ anthropologist]'s performance in moka [film festival circuit/peer-reviewed publications] or public life in general and his name or prestige. In fact, men [filmmakers/anthropologists] only achieve this state through a set of systematic separations that render the sphere in which they claim prestige apart from domestic activity [the production process/fieldwork], where they are, quite emphatically, not the singular proprietors of their own persons. (Strathern $1988,158)$

I offer this analogy to suggest the possibilities for domination implicated in collaborative ethnography once ethnographers exit the "field." Toby Lee (2019) has written about how, despite her own film's lack of profit, the accrual of symbolic and cultural capital — aided by her institutional affiliation — as the film screened at film festivals and museums ultimately contributed to her professional advancement as an artist and academic (Lee 2019, 144). ${ }^{16}$ In the case of Get By, my greater involvement and authority in the labor of production, post-production, and distribution - through filming, editing, color correction, sound mixing, and submitting the film to festivals - gave it a different value in exchange. In distribution spaces, such as festivals and conferences, my class position (and related social and cultural capital) was made to matter; it was I as the director who disproportionately benefited from the potential for prestige, if not profit. This accrual of exchange value is not unique to films; anthropologists know that the most salient currency for tenure and promotion is an ability to claim sole-authored books or films. I see parallels between the prestige accrued by Hagen men claiming non-singular work in a separate sphere and my authorship of this article - the publication of which will disproportionately benefit its "sole" author. If this very publication results in more interest in educational sales of the film, our profit-sharing agreement will also benefit Stanley and Milton, but not in a way that fundamentally shifts the asymmetries of our collaboration. In the case of films or written publications, circulation and prestige-making are removed by multiple degrees from the more collaborative sphere of production where filmmakers and anthropologists can hardly claim single proprietorship.

During the making of Get By, I attempted to work against the potential erasure of collaborative production by highlighting Milton's involvement in the filmmaking process. The scene of Milton watching the rough cut in the editing suite is followed by a conversation with me on what we should shoot next. He says, "If 
you want, I'll do it [ask the questions]; you just hold the camera!" (see Film Clip 2). Such moments have prompted audiences to remark on the film's seeming multiplicity in authorship, with one member saying, "it is clear that the film didn't belong to you from the very beginning." Yet this representation of multivocality could also be received as an omission of responsibility to my power as a filmmaker - after all, even in our back-and-forth, I remain off camera. As the director and editor, I ultimately retained the power to shape Stanley and Milton's stories through various invisible steps in the post-production and distribution processes.

Strathern's (1988) point regarding the "systematic separations" necessary for the transformation of a multiply produced object from one sphere to another resonates with anthropologists examining the dynamics of commodity chains. Anna Tsing (2013) has described how the commoditization of matsutake mushrooms, once "soaked through with communal obligations," is made possible by the multiple separations - in terms of people and place - between mushroom hunters, buyers, sorters, and exporters (Tsing 2013, 35). While Strathern (1988, 161) insisted on the impossibility of alienation in the gift economy, my experience with Get By suggests that the multiply produced film operates somewhere between a gift and a commodity economy. This finding echoes that of feminist scholars of capitalist inequality and anthropologists of exchange who critique the absolute dichotomies between gifts and commodities (Munn 1986; Gibson-Graham 2006 [1996]; Graeber 2011; Appadurai 2013; Tsing 2013) and between the market and other social worlds (Bear, Ho, Tsing, and Yanagisako 2015).

A focus on the (in)alienability of the multiply produced film has thus far highlighted how the seeming symmetries experienced during Get By's production belied the fundamental asymmetries in my access to circuits of distribution and associated prestige and profit. One further important aspect remains. In the case of the multiply produced pig, despite Hagen men's attempts to transform the domestic sociality of pig production into political prestige upon exchange, Strathern $(1988,161)$ is clear that the pig itself does not constitute property at the disposal of men. Instead, men's attempts at the transformation of value and any resulting prestige only further enchains them in relations of dependency with their spouses. Without resolving the alienability or inalienability of the multiply produced film, my experience making Get By suggests a similar dynamic. My recent interest in finding a distributor for the film, which would typically involve making claim to copyright ownership of an assumedly alienable film, actually led to deepened commitments to Milton and Stanley in terms of decision-making and profit-sharing. 


\section{MUTABILITY THROUGH TIME, SPACE, AND RESIGNIFICATION}

Another key concept from studies of asymmetrical exchange illuminating the dynamics of the multiply produced film is mutability. As exemplified in Nicholas Thomas's (1991) Entangled Objects, underlying the mutability of objects - to move from alienable commodity to inalienable gift or to be commodity and gift at once-entails a resignification facilitated by spatial and temporal separation. From a material perspective, objects themselves may remain unchanged, but their symbolic significance can be refigured over time or space; in other cases, objects may function simultaneously as commodities and expressions of relationships (N. Thomas 1991). Throughout the filmmaking process, footage is frequently mobilized as commodity and gift. "Work samples" showing the director's access to the intimate lives of film protagonists often result from off-camera friendships and are also used to convince film funders or distributors of the film's commercial potential.

Despite the ontological disagreements of scholars of asymmetrical exchange with regard to whether alienability is possible in a gift economy, the spatial and temporal separations between exchanges clearly introduce the possibility for different parties of the exchange to rewrite the narrative, benefiting as a result. John L. Jackson Jr. (2004) suggests that as with other gifts, the potential for exploitation for films is endless, as anthropologists can use footage shot for one thing to resignify it for another context, such as a journal article or a film festival. His use of the phrase "ethnographic filmflam" appears particularly apt because of the swindling enabled by the endless resignification of ethnographic material, evident in my own reusage of material for this article.

While making Get By, I was alerted to the risks of such variances in narrative resulting from the spatial and temporal gaps between the spheres of production and circulation. After completion, the film screened locally at Cornell Cinema, Stanley's church, and later, the Workers Unite Film Festival in New York City. I convinced the festival to cover transportation costs for Stanley and Milton, but at the last minute, neither could attend. The film screened at festivals and academic screenings internationally, including in Italy, Portugal, and France, out of which I could only attend one, and Stanley and Milton none.

It wasn't until years later, when I began volunteering for Stanley and Milton's TV show after that chance encounter with Milton, that I realized a misunderstanding about the film's circulation. One evening, after wrapping an episode, Stanley hesitantly asked me how the film was doing financially. I realized then that he must have long assumed I was profiting from the film's distribution. I made clear 
that, apart from the declined offer of transportation for the festival in New York, no monetary profit had come from the film's circulation. Sheepishly, I offered that if there had been, surely I would have shared the profits with them. Despite this admission, somewhere in the gap between a collaborative production process and its evidently less collaborative distribution, the film's (in)alienability and mutability brought our asymmetries into sharp focus.

Through the lens of mutability, the film exhibited characteristics of both gift and commodity. What began as a collaborative project prompted by a shared idea of the film's use value for the campaign transformed into a film with exchange value, partly due to my added labor through post-production. In this process, the inter-class aspect of our relationship became significant. Marx's analysis of commodity form focuses on the relationship between the working class (who provide labor) and capitalists (who provide capital). In my case, despite not having much capital (though I did use my own savings for film festival submission fees), following Lee (2019) and Pierre Bourdieu (1996), my social and cultural capital as a result of relative class and racial privilege, as well as my specialized labor, contributed to the film's commodification; in turn, the film's circulation at festivals and conferences further sedimented my social and cultural capital as an emerging film professional.

Despite my interest in reciprocal collaboration, I became party to the suturing involved in converting our seemingly inalienable film into an alienable commodity, abstracted from its collaborative origins. In this way, the multiply produced film resonates with Paige West's (2012, 55-56) argument that despite the "fair trade" market's deceptive ability to counter a Polanyian "disembedding" of the market from social relations, it is in fact an inescapable part of neoliberal commoditization. It would be fair to say that I became an unwitting ally to the decontextualization that enables the appearance of coherent capitalism (Bear, Ho, Tsing, and Yanagisako 2015). In sum, the seeming symmetries experienced during Get By's production belied the fundamental, class-based asymmetries in my ability to refashion the object - through strategies of post-production and access to circuits of distribution - and unequally benefit from prospects of prestige and profit.

\section{CONCLUSION}

After years of what might be characterized as a defensive/celebratory mode required by justifying new methods to a conservative discipline, visual anthropologists are increasingly turning their attention to the systems and institutions that produce and shape the technologies of their trade. Stephanie Takaragawa et al.'s 
(2019) "Bad Habitus" calls for a critical approach to examining how multimodal anthropology can reify power and privilege within systems of technoscience, global capitalism, and the white supremacist tendencies of anthropology (Todd 2018). Lee (2019), also informed by Bourdieu, is similarly reflexive in revealing how the self-professed "noncommercial” films made in Harvard's Sensory Ethnography Lab accrue massive cultural and social capital that allow them to circulate within prestige-based neoliberal economies of contemporary art. This article can also be situated within this vein of critically minded scholarship in which artist-anthropologists use one set of tools, critical ethnographic analysis, to examine other tools of their trade, films and other ethnographic technologies. In "open[ing] up the black box" (Takaragawa et al. 2019) to collaborative ethnographic filmmaking, the multiply produced film pulls focus on film as a technology, as well as on the practice of ethnography more broadly. In so doing, it concerns itself not only with the capitalist economy of value, as Takaragawa et al. (2019) and Lee (2019) do, but also with the gift economy of relations, intersecting arenas in which anthropologists both study and traffic.

Jean Rouch lamented the ways anthropologists consumed knowledge without offering much in return, assuming the role of metaphysical sorcerer or witch. Rouch (2003 [1973], 101) firmly believed that ethnographic film, while not resolving this dilemma, had the capacity to realize a "shared anthropology" (anthropologie partagée) in which "knowledge is no longer a stolen secret, devoured in the Western temples of knowledge." The strategies he developed to realize this vision included training interlocutors as filmmakers, "audiovisual reciprocity" (i.e., eliciting feedback from collaborators), and co-writing through "ethno-fiction." Yet even Rouch (2003 [1973], 221) struggled to resolve what I have described as the inherent tension between collaborative film as commodity and gift:

The people allow us to film them, but once it is done, the film goes to the West, and the people have no control over what is done with the images of their lives. Often the people who made the film have been given grants or get professional stature. Should the people be paid, too? Or is that another kind of insult?

This dilemma highlights what makes the ethnographic process confounding to all parties: that it cannot be said to exist squarely within either the gift economy or the market economy. 
Ethnography has long provided a unique toolbox for collaboration, though the explicit theorization of collaboration vis-à-vis the anthropology of exchange is more recent (Jackson 2004; Faubion and Marcus 2009; Rabinow 2011; Riles 2015). I have highlighted studies of asymmetrical exchange (i.e., on gender, colonialism) because, while once revelatory, their insights have not fundamentally transformed the ethnographic method. For this reason, I have chosen to "return to the scene" (Simpson 2014; Todd 2018) of the anthropology of exchange to draw a thread between its ontological insights and the epistemological contributions of feminist, decolonial, and visual anthropologists.

As I have argued, the multiply produced film does not make for an idealized form of collaboration; rather, it constitutes an analytic and a method that recognizes a fundamental tension between two dynamics common to ethnography - the gift-like exchanges of solidarity and obligation and the outwardly commoditized form produced by such exchanges_raising important questions about asymmetries of power, profit, and accountability. Despite the often nonmarket beginnings of collaborative ethnography - typically around a shared purpose (i.e., use value) — such exchange relations are disciplined through popular market conventions (Guyer 2004) and institutions (Gregory 1982) that contribute to the transformation of value from the spheres of production to circulation (Strathern 1988). First, ethnographic artifacts share outward appearances with commercially successful books and Hollywood blockbusters. Second, exchange relations are shaped by market-embedded institutions (e.g., festivals, distributors, academia) and subsequently the conditions and incentives for exchange value. Thus, regardless of if or when the prospect for profit is introduced, the gap between spheres of production and circulation contributes to the alienability, mutability, and commodification of collaborative objects.

I have suggested that when the object of collaborative efforts remains an immaterial intention, one can maintain faith in the ethical ideals of ethnographic solidarity. Yet the multiply produced film suggests that even efforts at "audio-visual reciprocity" (Rouch 2003 [1973]), “speaking nearby” (Trinh 1992), and "speaking with" (TallBear 2014) face an inevitable tension once social relations of solidarity are sutured into a material object. Thus, the very immaterial object that once served to build links between ethnographers and collaborators (owing to shared purpose or use value) is in danger of transforming from gift to commodity.

As a method, multiply produced ethnography creates openings for sharing intellectual and creative authority through fluid and changing roles in ways that recognize difference and its transformative potential for solidarity and intersub- 
jective knowledge production. Despite formalized methodological innovations aimed at leveling the playing field such as Co-authorship and participatory action research, such approaches often prove challenging because of the requirements of consistently shared priorities or privilege. The multiply produced method offers an emergent strategy (brown 2017) to transform some of the inherent limitations of ethnography — its long durée, its fundamental asymmetries - into openings for epistemological insight, by building on its core strengths such as its orientation to open-endedness, experimentation, and potential for multivocality.

I have suggested how, in the case of ethnographic film, the multiply produced can challenge Western norms of artistic autonomy and ownership by embracing a relational artistic autonomy through fluid roles, where directors can sometimes step back as camera persons while film "subjects" can put on the director's hat. Through creative contributions that engender a cascading multivocality, collaboration has the capacity to shape the filmic form itself. Continued experimentation with multiply produced methods in various subdisciplines of anthropology will, I hope, continue to further feminist and decolonial epistemological insights into forms of collaboration that are not only politically necessary but intellectually transformative.

I return to the politics of solidarity and the value of labor because many of the core insights of the multiply produced film stem from the relevance of the film's subject matter to the meta-questions raised by its production. The production of Get By, like the broader campaign for a living wage, sought to address the devaluation of working-class labor, especially by private contractors (e.g., recycling facilities) profiting from taxpayer money. In many ways, Stanley and Milton's labor was valued more highly within the gift economy in which their media and activist work operated than in the market through which they made their daily wage. One could say that the use value of the film for them was, in part, to increase the exchange value of their labor in the market. But the shared desires that fuel activism, organizing, and solidarity cannot be reduced to such instrumental analysis.

When I called Milton and Stanley to consult with them on the publication of this article, we reminisced about our days working together on the living wage campaign. Stanley recalled, "What we did was revolutionary!" Milton said, "If it wasn't for the film and our movement, fifteen dollars [i.e., the success of the "fight for fifteen" campaign advocating for raising the minimum wage to $\$ 15 /$ hour] never would have happened. That came from our hearts and minds!" He added, "When you become a famous director, I'll be able to say I was in your first film. You put us on the map with this film." While Milton's words are often kind and supportive to 
the point of exaggeration, these reflections reminded me of the positive outcomes of our work together despite my many regrets about the failed solidarity of the campaign and the filmmaking process. What stayed with him and Stanley was a sense of accomplishment with regard to their role in making the living wage a reality for other workers, even if it did little to benefit them personally (Milton was also eventually fired as a result of his activism).

The film's impact on any movement success - local or national-certainly was not a direct one; rather, it mediated, and in many ways produced, relations of thick solidarity that strengthened our relationships and shared work for the living wage. This stood in contrast to the thin solidarity that characterized aspects of the campaign in which the mobilization of empathy papered over differences of racialized class subjectivities, contributing to failures of accountability in moments of crisis.

While feminist accounts of collaboration often focus on the intersectional dynamics of two parties - the researcher and the researched-solidarity brings into view the significance of political alignments vis-à-vis a third, often more powerful party. If anthropological complicity in colonialism stems from the ignorance of this powerful "third," understanding the dynamics of solidarity has much to offer to pathways beyond the subject-object dyad of classic ethnography whose painful legacies continue to persist. Multiply produced ethnography builds on the intersectional feminist tradition to attend to the intersecting axes of difference and sameness to seek - however fraught and contingent - epistemologies of solidarity that aspire to weather the transformation of value and its emergent asymmetries throughout the ethnographic process.

\begin{abstract}
This article introduces the "multiply produced film" as a methodology and analytic that highlights the asymmetrical dynamics inherent to collaboration. I draw on (auto)ethnographic material from the making of Get By (2014), a film on worker-community solidarity, to explore collaboration across race, class, and gender in subject matter and method. I situate the multiply produced film within a genealogy that grafts ontological insights from the anthropology of exchange onto the epistemological contributions of feminist, decolonial, and visual anthropologists committed to collaboration. I argue that as a method, collaborative filmmaking has the potential to challenge narrow Western conceptions of autonomy and authorship through shared authority and fluid roles that engender a cascading multivocality that shapes the resulting filmic form. As an analytic, the multiply produced film reveals how collaboration entails a fundamental tension between the gift-like exchanges of solidarity and
\end{abstract}


the outwardly commoditized form (e.g., films, books) produced by such exchanges, raising questions about asymmetries of power, prestige, and accountability. [ethnographic film; collaboration; the gift; feminist epistemology; visual anthropology; decolonizing anthropology; solidarity]

\section{NOTES}

Acknowledgments I want to thank Milton Webb and Stanley McPherson for being courageous and patient co-adventurers in our filmmaking and organizing journey together. Without their friendship, deep commitment, and creative insights, Get By, this article, and the living wage campaign would never have borne any fruit. I am grateful to fellow organizers from the Cornell Organization for Labor Action and the Tompkins County Workers' Center Living Wage Working Group for their hard work on the campaign and their willingness to be in front of the camera. My deep appreciation goes to my filmmaking mentor J. P. Sniadecki and fellow filmmaking students in Cornell's "Sub-basement Cinema," especially Miasarah Lai, Mariangela Mihai, and Natalie Nesvaderani, now fellow members of Ethnocine Collective. I could not have finished this article without the many people who offered invaluable feedback on earlier versions, including Annelise Riles, Elena Guzman, Guangtian Ha, Shannan Hayes, Zoë West, Kriangsak Teera-Hong, Noorjehan Asim, Erica Kaunang, and the generous peer reviewers. Finally, I wish to thank Heather Paxson for her keen eye and exceptional guidance, which made this article stronger in ways I could not have envisioned.

1. See the Tompkins County Workers' Center website for more on the living wage campaign, http://www.tcworkerscenter.org/community/faq-on-mw-as-lw-campaign/.

2. See Gabriel Dattatreyan $(2018,23)$ on whether collaborative ethnography necessarily engenders obligation or imposition.

3. See Faye V. Harrison (1991) and Irma McClaurin (2001) on anthropology's failures to cite the work of women and people of color-significant given that concrete pathways to decolonizing the discipline have been advanced primarily by women and scholars of color.

4. Green (2015) and other filmmakers argue that the conventional term film subjects does not afford agency to those whose lives are on screen, instead advocating for terms such as participants, collaborators, protagonists, or characters.

5. For example, Green's (2015) “co-collaboration” articulates a reflexive, intersubjective practice between researcher and researched that challenges the hierarchical relationship between the two. Jackson's (2004) "ethnographic filmflam" emphasizes the potential for disingenuousness when anthropologists repurpose filmic material for unanticipated ethnographic ends.

6. The methodology of the multiply produced film could be seen as in keeping with calls for "patchwork ethnography," which contests conventional notions and temporalities of "the field" and aims to transform existing constraints into openings for new epistemological insights (Günel, Varma, and Watanabe 2020).

7. Such accounts resonated with my own experiences as a perennial insider-outsider, as a person of mixed heritage raised on three continents. This is a position that, while once painful, I have come to embrace as an anthropologist and a filmmaker.

8. The term cinéma vérité (Rouch 2003 [1973]), vérité for short, describes scenes of unfolding action and everyday life in contrast to interviews or voice-over paired with B-roll. While the term has been critiqued even by its author for its problematic mobilization of "truth," I mobilize it to signify a filmic sensibility of directness and intimacy cultivated through relationships with collaborators. The potential for cinéma vérité to challenge the "fly on the wall" aesthetics of "purely" observational film makes it particularly generative for decolonial and feminist approaches that view the director as a participant rather than outside of what is filmed. 
9. Despite the prevailing artistic norms of single authorship advanced by filmic "auteur theory" (Truffaut 2014 [1954]), a range of attitudes and practices exist regarding collaboration in ethnographic filmmaking. The work of Harvard's Sensory Ethnography Lab involves collaboration with fellow filmmakers (Lee 2019) but not typically with film "subjects." On the other end of the spectrum, the legacy of filmmakers such as Jean Rouch, who consciously practiced "shared anthropology" and whose films (e.g., Rouch 1961) incorporate reflexive feedback from film participants, is increasingly being taken up by a new generation of indigenous, feminist, and decolonial ethnographic filmmakers and collectives like the Karrabing Film Collective, Miyarrka Media, CAMRA, and Ethnocine Collective, the latter of which I am a member.

10. One barbershop interviewee's comments on Black entrepreneurship advocates for a solution seemingly at odds with the demands of the living wage campaign — working for oneself.

11. This history of solidarity includes the Black-led civil rights movement paving the way for the Immigration Act of 1965 and Black solidarity after the murder of Vincent Chin by two white men in 1982. Histories of conflict bring to mind the racialized tensions between Black and Korean communities during the 1992 Los Angeles uprising and the ways in which the "model minority" myth is weaponized by white supremacist narratives against affirmative action and the Movement for Black Lives.

12. I was born and raised in Korea, in a culture emphasizing relational social intelligence. The Korean notion of nunchi considers the ability to perceive and act on others' needs, desires, and emotions (in relation to one's own) as a basic tenet of social relations.

13. Such a moment is captured in another film I co-directed, For My Art (Hong, Lai, and Mihai 2016). Similarly, as a producer of the Bad Feminists Making Films podcast, I have found that a common challenge for female directors is managing male crew members who refuse their directorial authority, going so far as to pose as the director on set.

14. While the PAR process emphasizes the multiple voices of stakeholders, written projects often necessitate multiple voices speaking as one, in the form of conclusions and recommendations. One aspect of Get By that confounds more conventional documentary styles is how it does not articulate a single closed message. This results from the "cascading multivocality" that began with Milton's imperative to include more community voices on the living wage. This openness has allowed the film to invite very different kinds of discussions - from a community screening in Stanley's church with local politicians and leaders, to a conference on the "Right to the City" with labor scholars and activists in Paris, to the Workers Unite Film Festival in New York. The approach to producing Get By, my first film, can be described as an exercise in "emergent strategy" (brown 2017); I have learned from its successes and failures. Street PAR (SPAR) — challenging to attempt because of the sheer time required of its stakeholders, who are involved in every stage of the project (Payne and Bryant 2018) — provides important lessons for collaborative and impact-oriented filmmaking. For example, the SPAR approach to discuss ownership of the research from the outset (Bryant and Payne 2013) constitutes a critically important ethical practice. My current film project takes a similar approach, with meta-conversations at every stage of the process, from development to post-production, including conversations about film credits and funding. An increasing number of nonfiction filmmakers are taking up such approaches to increase transparency with and accountability to film participants (see Documentary Accountability Working Group 2021; https://www.docaccountability.org/).

15. Feminist ethnographers have long pursued methods of co-authorship and multivocality (Moraga and Anzaldúa 2015 [1981]; Lawless 1991; Behar and Gordon 1995; Torres 2019; El Kotni, Dixon, and Miranda 2020).

16. See Heather Paxson (2013) for an explanation of "ethnographic complicity," which describes how research "subjects," in this case artisan cheesemakers, view her scholarship as adding value to their commodities, to the point that one artisan dairy sold her book as part of a $\$ 75$ "cheese nerd" gift box. 


\section{REFERENCES}

Abu-Lughod, Lila

1988 "Fieldwork of a Dutiful Daughter." In Arab Women in the Field: Studying Your Own Society, edited by Soraya Altorki and Camillia Fawzi El-Solh, 139-61. Syracuse, N.Y.: Syracuse University Press.

Allen, Jafari Sinclaire, and Ryan Cecil Jobson

2016 "The Decolonizing Generation: (Race and) Theory in Anthropology since the Eighties." Current Anthropology 57, no. 2: 129-48. https://doi.org/10.1086/685502.

Anzaldúa, Gloria E., and AnaLouise Keating

2015 Light in the Dark / Luz en lo Oscuro: Rewriting Identity, Spirituality, Reality. Durham, N.C.: Duke University Press.

Appadurai, Arjun

2013 The Social Life of Things: Commodities in Cultural Perspective. Cambridge: Cambridge University Press.

Asad, Talal, ed.

1998 Anthropology and the Colonial Encounter. Amherst, N.Y.: Humanity Books. Originally published in 1973.

Atshan, Sa'ed, and Darnell L. Moore

2014 "Reciprocal Solidarity: Where the Black and Palestinian Queer Struggles Meet." Biography 37, no. 2: 680-705. http://doi.org/10.1353/bio.2014.0033.

Bear, Laura, Karen Ho, Anna Lowenhaupt Tsing, and Sylvia Yanagisako

2015 "Gens: A Feminist Manifesto for the Study of Capitalism. Society for Cultural Anthropology." Theorizing the Contemporary, Fieldsights, March 30. https:// culanth.org/fieldsights/gens-a-feminist-manifesto-for-the-study-of-capitalism.

Behar, Ruth, and Deborah A. Gordon, eds.

1995 Women Writing Culture. Berkeley: University of California Press.

Bourdieu, Pierre

1996 The Rules of Art: Genesis and Structure of the Literary Field. Translated by Susan Emmanual. Stanford, Calif.: Stanford University Press.

brown, adrienne maree

2017 Emergent Strategy: Shaping Change, Changing Worlds. Chico, Calif.: AK Press.

Bryant, Angela, and Yasser Payne

2013 "Evaluating the Impact of Community-Based Learning: Participatory Action Research as a Model for Inside-Out." In Turning Teaching Inside Out: A Pedagogy of Transformation for Community-Based Education, edited by Simone Weil Davis and Barbara Sherr Roswell, 227-39. New York: Palgrave Macmillan.

Cho, Sumi, Kimberlé Williams Crenshaw, and Leslie McCall

2013 "Toward a Field of Intersectionality Studies: Theory, Applications, and Praxis." Signs 38, no. 4: 785-810. https://doi.org/10.1086/669608.

Comaroff, Jean, and John L. Comaroff

1991 Of Revelation and Revolution, Volume 1: Christianity, Colonialism, and Consciousness in South Africa. Chicago: University of Chicago Press.

Crenshaw, Kimberle

1991 "Mapping the Margins: Intersectionality, Identity Politics, and Violence against Women of Color." Stanford Law Review 43, no. 6: 1241-99. https://doi. org/10.2307/1229039.

Dattatreyan, Gabriel

2018 "Critical Hip-Hop Cinema: Racial Logics and Ethnographic Ciphas in Delhi." Wide Screen 7, no. 1. http://widescreenjournal.org/index.php/journal/article/ view/119.

Dattatreyan, Ethiraj Gabriel, and Isaac Marrero-Guillamón

2019 "Introduction: Multimodal Anthropology and the Politics of Invention." American Anthropologist 121, no. 1: 220-28. https://doi.org/10.1111/aman.13183. 
Dean, Jodi

1996 Solidarity of Strangers: Feminism after Identity Politics. Berkeley: University of California Press.

Documentary Accountability Working Group

2021 "Framework for Ethical and Accountable Nonfiction Filmmaking." Unpublished manuscript.

El Kotni, Mounia, Lydia Z. Dixon, and Veronica Miranda

2020 "Introduction: Co-authorship as Feminist Writing and Practice." Member Voices, Fieldsights, February 6. https://culanth.org/fieldsights/introduction-coauthorship-as-feminist-writing-and-practice.

Evans-Pritchard, E. E.

1946 "Applied Anthropology." Africa: Journal of the International African Institute 16, no. 2: 92-98. https://doi.org/10.2307/1157018.

Fabian, Johannes

1983 Time and the Other: How Anthropology Makes Its Object. New York: Columbia University Press.

Fassin, Didier

2012 Humanitarian Reason: A Moral History of the Present. Translated by Rachel Gomme. Berkeley: University of California Press.

Faubion, James D., and George E. Marcus, eds.

2009 Fieldwork Is Not What It Used to Be: Learning Anthropology's Method in a Time of Transition. Ithaca, N.Y.: Cornell University Press.

Gibson-Graham, J. K.

2006 The End of Capitalism (As We Knew It): A Feminist Critique of Political Economy. Minneapolis: University of Minnesota Press. Originally published in 1996.

Ginsburg, Faye

2018 "Decolonizing Documentary On-Screen and Off: Sensory Ethnography and the Aesthetics of Accountability" Film Quarterly 72, no. 1: 39-49. https://doi.

Graeber, David org/10.1525/fq.2018.72.1.39.

2011 Debt: The First 5,000 Years. Brooklyn, N.Y.: Melville House.

Green, Kai M.

2011 It Gets Messy in Here.

2015 "The Essential I/Eye in We: A Black TransFeminist Approach to Ethnographic Film." Black Camera 6, no. 2: 187-200. https://muse.jhu.edu/article/583181.

Greenwood, Davydd J., and Morten Levin

2007 Introduction to Action Research: Social Research for Social Change. 2nd ed. Thousand

Gregory, C. A. Oaks, Calif.: Sage.

1982 Gifts and Commodities. London: Academic Press.

Griffin, Rachel Alicia

2012 "I AM an Angry Black Woman: Black Feminist Autoethnography, Voice, and Resistance." Women's Studies in Communication 35, no. 2: 138-57. https://doi.org/1 0.1080/07491409.2012.724524.

Günel, Gökçe, Saiba Varma, and Chika Watanabe

2020 “A Manifesto for Patchwork Ethnography." Member Voices, Fieldsights, June 9.

Guyer, Jane I. https://culanth.org/fieldsights/a-manifesto-for-patchwork-ethnography.

2004 Marginal Gains: Monetary Transactions in Atlantic Africa. Chicago: University of Hale, Charles R. Chicago Press.

2006 "Activist Research v. Cultural Critique: Indigenous Land Rights and the Contradictions of Politically Engaged Anthropology." Cultural Anthropology 21, no. 1: 96-120. https://doi.org/10.1525/can.2006.21.1.96. 
Hall, Stuart, Chas Critcher, Tony Jefferson, John N. Clarke, and Brian Roberts

1978 Policing the Crisis: Mugging, the State, and Law and Order. London: Macmillan.

Harrison, Faye V., ed.

1991 Decolonizing Anthropology: Moving Further toward an Anthropology for Liberation.

Hemment, Julie Washington, D.C.: Association of Black Anthropologists.

2007 Empowering Women in Russia: Activism, Aid, and NGOs. Bloomington: Indiana

Hong, Emily University Press.

2014 Get By. Ethnocine Collective.

Hong, Emily, Miasarah Lai, and Mariangela Mihai

2016 For My Art. Ethnocine Collective.

Jackson, John L., Jr.

2004 "An Ethnographic Filmflam: Giving Gifts, Doing Research, and Videotaping the Native Subject/Object." American Anthropologist 106, no. 1: 32-42. https://doi. org/10.1525/aa.2004.106.1.32.

2010 "In Medias Race (and Class): Post-Jim Crow Ethnographies of Black Middleclassdom.” Du Bois Review 7, no. 1, 35-39. https://doi.org/10.1017/ S1742058X10000019.

Jobson, Ryan Cecil

2020 "The Case for Letting Anthropology Burn: Sociocultural Anthropology in 2019." American Anthropologist 122, no. 2: 259-71. https://doi.org/10.1111/aman.13398.

Juris, Jeffrey S., and Alex Khasnabish, eds.

2013 Insurgent Encounters: Transnational Activism, Ethnography, and the Political. Durham, N.C.: Duke University Press.

Lassiter, Luke Eric

2008 "Editor's Introduction." Collaborative Anthropologies 1: vii-xii. https://doi. org/10.1353/cla.0.0006.

Lawless, Elaine J.

1991 "Women's Life Stories and Reciprocal Ethnography as Feminist and Emergent." Journal of Folklore Research 28, no. 1: 35-60. https://www.jstor.org/stable/3814539.

Lee, Toby

2019 "Beyond the Ethico-aesthetic: Toward a Re-valuation of the Sensory Ethnography Lab.” Visual Anthropology Review 35, no. 2: 138-47. https://doi.org/10.1111/ var.12184.

Liu, Roseann, and Savannah Shange

2018 "Toward Thick Solidarity: Theorizing Empathy in Social Justice Movements." Radical History Review 2018, no. 131: 189-98. https://doi.org/10.1215/016365454355341.

Low, Setha M., and Sally Engle Merry

2010 "Engaged Anthropology: Diversity and Dilemmas; An Introduction to Supplement 2." Current Anthropology 51, no. S2: S203-26. https://doi.org/10.1086/653837.

Malinowski, Bronislaw

1929 "Practical Anthropology." Africa 2, no. 1: 22-38. https://doi.org/10.2307/1155162.

McClaurin, Irma, ed.

2001 Black Feminist Anthropology: Theory, Politics, Praxis, and Poetics. New Brunswick, N.J.: Rutgers University Press.

McPherson, Stanley, and Milton Webb

2014 What Matters at the Round Table. Produced by Stanley McPherson. Pegasys Public Access Channel 13.

Mohanty, Chandra Talpade

2003 Feminism without Borders: Decolonizing Theory, Practicing Solidarity. Durham, N.C.: Duke University Press. 
Moraga, Cherríe, and Gloria Anzaldúa, eds.

2015 This Bridge Called My Back: Writings by Radical Women of Color. 4th ed. Albany, N.Y.: SUNY Press. Originally published in 1981.

Munn, Nancy D.

1986 The Fame of Gawa: A Symbolic Study of Value Transformation in a Massim (Papua New Guinea) Society. Cambridge: Cambridge University Press.

Narayan, Kirin

1993 “How Native Is a 'Native' Anthropologist?” American Anthropologist 95, no. 3: 67186. https://doi.org/10.1525/aa.1993.95.3.02a00070.

Paxson, Heather

2013 "Crafting Cheese, Making Knowledge: What American Cheesemakers and Their Ethnographer Hold in Common.” Paper presented at the American Anthropological Association Annual Meeting, Chicago, November 20-24.

Payne, Yasser Arafat, and Angela Bryant

2018 "Street Participatory Action Research in Prison: A Methodology to Challenge Privilege and Power in Correctional Facilities." Prison Journal 98, no. 4: 449-69. https://doi.org/10.1177/0032885518776378.

Pels, Peter

2008 "What Has Anthropology Learned from the Anthropology of Colonialism?" Social Anthropology 16, no. 3: 280-99. https://doi.org/10.1111/j.14698676.2008.00046.x.

Perry, Keisha-Khan Y.

2014 "State Violence and the Ethnographic Encounter: Feminist Research and Racial Embodiment." In Bridging Scholarship and Activism, edited by Bernd Reiter and Ulrich Oslender. East Lansing: Michigan State University Press.

Rabinow, Paul

2011 The Accompaniment: Assembling the Contemporary. Chicago: University of Chicago Press.

Rappaport, Joanne

2008 "Beyond Participant Observation: Collaborative Ethnography as Theoretical Innovation.” Collaborative Anthropologies 1: 1-31. https://doi.org/10.1353/ cla.0.0014.

Riles, Annelise

2015 "From Comparison to Collaboration: Experiments with a New Scholarly and Political Form." Law and Contemporary Problems 78, no. 1/2: 147-83. https:// scholarship.law.duke.edu/lcp/vol78/iss1/7.

Rouch, Jean

1961 Chronicle of a Summer.

2003 Ciné-Ethnography. Edited and translated by Steven Feld. Minneapolis: University of Minnesota Press. Originally published in 1973.

Simmons, Kimberly Eison

2001 "A Passion for Sameness: Encountering a Black Feminist Self in Fieldwork in the Dominican Republic." In Black Feminist Anthropology: Theory, Politics, Praxis, and Poetics, edited by Irma McClaurin, 77-101. New Brunswick, N.J.: Rutgers

Simpson, Audra University Press.

2014 Mohawk Interruptus: Political Life across the Borders of Settler States. Durham, N.C.: Duke University Press.

Slocum, Karla

2001 “Negotiating Identity and Black Feminist Politics in Caribbean Research.” In Black Feminist Anthropology: Theory, Politics, Praxis, and Poetics, edited by Irma McClaurin, Stacey, Judith 126-49. New Brunswick, N.J.: Rutgers University Press.

1988 “Can There Be a Feminist Ethnography?" Women's Studies International Forum 11, no. 1: 21-27. https://doi.org/10.1016/0277-5395(88)90004-0. 
Strathern, Marilyn

1988 The Gender of the Gift: Problems with Women and Problems with Society in Melanesia. Berkeley: University of California Press.

Sudbury, Julia, and Margo Okazawa-Rey, eds.

2009 Activist Scholarship: Antiracism, Feminism, and Social Change. Boulder: Paradigm.

Takaragawa, Stephanie, Trudi Lynn Smith, Kate Hennessy, Patricia Alvarez Astacio, Jenny

Chio, Coleman Nye, and Shalini Shankar

2019 "Bad Habitus: Anthropology in the Age of the Multimodal." American Anthropologist 121, no. 2: 517-24. https://doi.org/10.1111/aman.13265.

TallBear, Kim

2014 "Standing with and Speaking as Faith: A Feminist-Indigenous Approach to Inquiry." Journal of Research Practice 10, no. 2: N17. http://jrp.icaap.org/index.php/ jrp/article/view/405.

Thomas, Deborah A.

2018. "Decolonizing Disciplines." American Anthropologist 120, no. 3: 393-97. https://doi. $\operatorname{org} / 10.1111 /$ aman.13102.

Thomas, Nicholas

1991 Entangled Objects: Exchange, Material Culture, and Colonialism in the Pacific. Cambridge, Mass.: Harvard University Press.

Todd, Zoe

2018 “The Decolonial Turn 2.0: The Reckoning.” Anthro\{dendum\}, June 15. https:// anthrodendum.org/2018/06/15/the-decolonial-turn-2-0-the-reckoning/.

Torres, M. Gabriela

2019 "Feminist Anthropology Is Teamwork." Anthropology News 60, no. 6: e142-e144. https://doi.org/10.1111/AN.1305.

Trinh T. Minh-ha

1992 “'Speaking Nearby’: A Conversation with Trinh T. Minh-ha.” By Nancy N. Chen. Visual Anthropology Review 8, no. 1: 82-91. https://doi.org/10.1525/var.1992.8.1.82.

Truffaut, François

2014 “A Certain Tendency in French Cinema (France, 1954)." In Film Manifestos and Global Cinema Cultures, edited by Scott MacKenzie, 133-44. Berkeley: University of California Press.

Tsing, Anna

2013 "Sorting out Commodities: How Capitalist Value Is Made through Gifts." HAU: Journal of Ethnographic Theory 3, no. 1: 21-43. https://doi.org/10.14318/ hau3.1.003.

Ulysse, Gina A.

2007 Downtown Ladies: Informal Commercial Importers, a Haitian Anthropologist, and SelfMaking in Jamaica. Chicago: University of Chicago Press.

Visweswaran, Kamala

1994 Fictions of Feminist Ethnography. Minneapolis: University of Minnesota Press.

Weiner, Annette B.

1992 Inalienable Possessions: The Paradox of Keeping-While-Giving. Berkeley: University of California Press.

West, Paige

2012 From Modern Production to Imagined Primitive: The Social World of Coffee from Papua New Guinea. Durham, N.C.: Duke University Press. 